\title{
The Process Skills Approach with Mind Map Media Through Lesson Study Improving Students' Learning Outcomes
}

\author{
Muhsinah Annisa ${ }^{1^{*}}$, Fadhlan Muchlas Abrori ${ }^{2}$, Sucahyo Mas'an Al-Wahid ${ }^{3}$, \\ M. Nordiansyach ${ }^{4}$, Risma ${ }^{5}$, Hasbiah ${ }^{6}$, Dessy Putri Amelia ${ }^{7}$, Sari Damara Gita ${ }^{8}$ \\ 1,3,5,6,7,8 Department of Elementary School Teacher Education, Universitas Borneo Tarakan, Tarakan, Indonesia \\ ${ }^{2}$ Department of Biology Education, Universitas Borneo Tarakan, Tarakan, Indonesia \\ ${ }^{4}$ Sekolah Dasar Negeri 020 Tarakan, Tarakan, Indonesia \\ e-mail: echa.ok@gmail.com ${ }^{1}$, fadhlan1991@gmail.com²
}

\begin{abstract}
This study aims to analyze the effectiveness of mindmap-assisted process skills approach through lesson study in improving students' learning outcomes This study uses qualitative approach with descriptive research type. The subjects of this study were students of class VB. Implementation of the lesson study cycle is carried out 13 times cycles, with details of the first lesson study model's eight cycles for the lesson study teacher and the next five cycles for the model teacher. The data collection instruments are the teachers' learning implementation sheet and student worksheets to assess student learning outcomes in each cycle. Student learning outcomes in the implementation of lesson study by teacher model lecturers have the lowest average (54.0667) in the first LS cycle, while the highest average (71.7667) in the eighth LS cycle. So, it can be concluded that applying the mindmap-assisted process skills approach through lesson study can improve student learning outcomes.
\end{abstract}

Keywords: Lesson study, Process Skill, Mindmap

\section{Introduction}

The government currently has made various efforts to improve teacher competencies. Each teacher is expected to achieve competent teacher criteria based on four teacher competencies: pedagogical, personality, social and professional (Merukh \& Sulasmono, 2016; Muspawi, 2017; Prayitno, 2019). One of the government's efforts to encourage teachers to be more competent is by holding teacher certification. However, this method is not very effective in increasing teacher competence. Students' perceptions in Indonesia state that there is no difference between certified teachers and uncertified teachers. Ujian Kompetensi Guru (Teacher Competency Test/UKG) by the Ministry of Education and Culture showed that the average UKG score for elementary school teachers for certified teachers is 54.2 . This score is not much different from the uncertified teacher, which is 54.3.

The low score of UKG reflects the competence of the teacher itself. The low UKG score illustrates the number of teachers who are not yet competent in carrying out their duties (Maiza \& Nurhafizah, 2019; Setiawan \& Sitorus, 2017). Generally, in Indonesia, the school level's improvement efforts only refer to learning outcomes and do not refer to the learning process, so that the essence of the teacher's job as a competent person is not overly assessed. Responding to the lack of teacher competence in Indonesia, the Ministry of Research, Technology and Higher Education through the Penugasan Dosen di Sekolah (School Assignment Grant Program/PDS) designed a program between lecturers and teachers to share learning. On the one hand, lecturers can present real experiences in learning at school, and on the other hand, teachers in schools get suggestion related to the learning process in the classroom. Maximum achievement in PDS activities requires active sharing between the two parties.

Before implementing learning activities in class, the lecturer made initial observations in the class where the partner teacher taught. Initial observations were carried out in class VB

\footnotetext{
${ }^{*}$ Corresponding author.

Received 15 April 2020; Accepted 18 September 2020; Available online 25 March 2021 (C) 2020 JPI. All Rights Reserved
} 
SDN 020 Tarakan. Based on the preliminary observations, it was concluded that there were problems from the aspect of teacher teaching and had an impact on student learning outcomes. Learning in the classroom still rarely involves students in solving a problem and is mostly dominated by teachers. Teachers also rarely apply learning media in the classroom, so class activities are limited to lectures (by the teacher), reading (by students), and closed by completing assignments in books. The impact of this learning process is on the percentage of student completeness. Completeness of learning outcomes, especially in thematic learning is low; only $57 \%$ of students' experience completeness.

One way to improve learning outcomes is to use a process skills approach. Learning using a process skills approach encourages students to think through observation, interpret observations, classify, predict, communicate and ask questions, thus enabling students to develop their thinking skills (Alamsyah et al., 2018; Naj'iyah et al., 2020). Process skills can also train students to think scientifically and systematically (Sayekti \& Kinasih, 2018; I. Yusuf \& Widyaningsih, 2018). The process skills approach is fundamental in learning because it is one of the approaches used to learn and understand a concept in learning formulated in learning objectives. Process skills broadly consist of necessary skills, practical process skills and causative process skills (Çepni, 2005). Students can also use process skills in responding to problems personally, socially, and globally (Huppert et al., 2010). Process skills can also be described as physical and mental abilities used in effective learning to carry out investigations and knowledge discovery which are described in describing, predicting and explaining certain phenomena (Asabe \& Yusuf, 2016)

There is a need for appropriate learning media to support the process skills approach in learning. With media presence in the learning process, teachers can provide ideas and clarity so that knowledge and learning experiences can be more straightforward and more comfortable for students to understand (Saputri, 2018). One of the suitable learning media is the mind map. With a mind map, students can take creative and useful notes. Besides, students can map the concepts they learn in an attractive, easy and efficient manner (Hendawati et al., 2018). Mind maps can be used effectively because they help students in making conceptual ramifications on the specific material. Mind maps can be interpreted as graphs/images representing the relationship between concepts and ideas related to a central subject (Magdalena et al., 2014; Yusuf \& Amin, 2016; Zahro et al., 2018). Students put the main topic (central subject) in the middle and connect the main topic with concepts and ideas based on the relationship using lines. Lines represent relationships and are usually annotated. The combination of the mind map assisted process skills approach is expected to improve student learning outcomes and the learning process that impacts student learning outcomes.

Based on the observations found regarding the percentage of student completeness and the learning process conditions in the teacher-centred class, it is necessary to make efforts to solve this problem. One of the solutions offered is applying a mind map-assisted process skills approach through lesson study (LS). Through lesson study, teachers can develop professional learning development programs by making maximum use of facilities and infrastructure and providing opportunities for teachers to know the nature of learning (learning how to learn and learn about teaching).

Stigler and Hiebert (1999) state that lesson study involves groups of teachers who meet regularly within a certain period of time (within a few months or up to a year) to design, implement, test, and develop research in learning. Lewis and Tsuchida (1998) state that research in learning that is emphasized in the lesson study includes: (a) a focus on general teacher problems, goals and visions of pedagogical practice; (b) carefully designed, usually in collaboration with one or more colleagues (other teachers, lecturers, principals or education practitioners); (c) observed by colleagues; (d) recorded for analysis and reflection; and (e) discussed through the lesson study group.

The impact of the lesson study is very diverse. Generally, the initial impact is in the form of a shift in the teacher's paradigm in learning which has an impact on how teachers teach. Teachers will increasingly develop their competence in learning based on input from colleagues who make observations. Yurnetti (2018) states that lesson study is able to change the point of view of teachers that teaching is not just a "personal matter" but is an integral part 
of a group of teachers. Lesson studies need support from the school to facilitate teachers as teachers with other colleagues (other teachers, lecturers, school principals and education practitioners).

Lesson study was first known in Japan, where teachers in Japan used a lot of experience in the observation activity known as Jugyou kenkyuu. Jugyou kenkyuu was eventually adapted outside of Japan and is known as lesson study. The cycle duration of lesson study in Japan is generally more than 5 weeks (Murata and Takahashi, 2002; Takahashi and McDougal. 2016). This long period of time helps the teacher and colleagues to design an exciting lesson so that the results obtained in the classroom are maximized

Based on the above considerations, learning was carried out by implementing a process skills approach assisted by mind map media through lesson study for $5^{\text {th }}$ grade elementary school students.

\section{Method}

This research is a research with a qualitative approach, which is a descriptive study. The subjects of this study were students of class VB SDN 020 Tarakan. The research focus was on lesson study activities carried out collaboratively between class VB teachers at SDN 020 Tarakan and FKIP lecturers at the University of Borneo Tarakan (UBT). This study described the implementation of the mind map assisted process skills approach through lesson study. This study aimed to improve student learning outcomes by applying the mindmapassisted process skills approach through lesson study. The design of the lesson studies refers to the lesson study activities conducted by Grimsæth and Hallås (2015), where the lesson studies was carried out alternately with several model teachers. In the research conducted in this PDS activity, lesson study was carried out in two stages, namely: lesson study with model teachers by lecturers and lesson study with model teachers by class teachers.

The implementation of the LS cycle was carried out in 13 cycles, with details of the first 8 LS cycles the LS model teacher was a UBT lecturer and the next five cycles the model teacher was an SDN 020 Tarakan teacher. The LS which was carried out by the lecturer as a model teacher will be a reference or example for the teacher to implement the LS in the classroom. The implementation of the first eight cycles provides an overview of the class teacher (who also acts as an observer) in the implementation of learning activities through the LS so that in the next stage the teacher and lecturer worked collaboratively to design, implement and reflect on learning through the next LS cycle.

Overall, the implementation of LS started from September 10, 2018, and ended on October 17, 2018. The total number of LS implementers consisted of 1 model teacher and six observers. The activity schedule table for the implementation of LS is described in Table 1 and Table 2.

Table 1. Implementation Schedule for LS with a UBT lecturer as model teacher

\begin{tabular}{|c|c|c|c|c|c|c|}
\hline No & Activity & $\begin{array}{l}\text { LS } \\
\text { Cycle }\end{array}$ & $\begin{array}{l}\text { Date and } \\
\text { Month }\end{array}$ & $\begin{array}{l}\text { Model } \\
\text { Teacher }\end{array}$ & Observers & $\begin{array}{l}\text { Thematic } \\
\text { Content }\end{array}$ \\
\hline 1 & $\begin{array}{l}\text { Plan } \\
\text { Do }\end{array}$ & $1^{\text {st }}$ & $\begin{array}{l}10 \text { September } \\
12 \text { September }\end{array}$ & MA & $\begin{array}{l}\text { FMA, SMA, MN, } \\
\text { R, H, dan D }\end{array}$ & $\begin{array}{c}\text { Theme } 3 \\
\text { Sub Theme } \\
1\end{array}$ \\
\hline 2 & $\begin{array}{l}\text { See } \\
\text { Plan } \\
\text { Do } \\
\text { See }\end{array}$ & $2^{\text {nd }}$ & $\begin{array}{l}12 \text { September } \\
13 \text { September } \\
14 \text { September } \\
15 \text { September }\end{array}$ & MA & $\begin{array}{l}\text { FMA, SMA, MN, } \\
\text { R, H, dan D }\end{array}$ & $\begin{array}{c}\text { Theme } 3 \\
\text { Sub Theme } \\
1\end{array}$ \\
\hline 3 & $\begin{array}{l}\text { Plan } \\
\text { Do } \\
\text { See }\end{array}$ & $3^{\text {rd }}$ & $\begin{array}{l}21 \text { September } \\
24 \text { September } \\
24 \text { September }\end{array}$ & MA & $\begin{array}{l}\text { FMA, SMA, MN, } \\
\text { R, H, dan D }\end{array}$ & $\begin{array}{c}\text { Theme } 3 \\
\text { Sub Theme } \\
2\end{array}$ \\
\hline 4 & $\begin{array}{l}\text { Plan } \\
\text { Do } \\
\text { See }\end{array}$ & $4^{\text {th }}$ & $\begin{array}{l}25 \text { September } \\
26 \text { September } \\
26 \text { September }\end{array}$ & MA & $\begin{array}{c}\text { FMA, SMA, MN, } \\
\text { R, H, dan D }\end{array}$ & $\begin{array}{c}\text { Theme } 3 \\
\text { Sub Theme } \\
2\end{array}$ \\
\hline
\end{tabular}




\begin{tabular}{|c|c|c|c|c|c|c|}
\hline No & Activity & $\begin{array}{c}\text { LS } \\
\text { Cycle }\end{array}$ & $\begin{array}{l}\text { Date and } \\
\text { Month }\end{array}$ & $\begin{array}{l}\text { Model } \\
\text { Teacher }\end{array}$ & Observers & $\begin{array}{c}\text { Thematic } \\
\text { Content }\end{array}$ \\
\hline 5 & $\begin{array}{l}\text { Plan } \\
\text { Do } \\
\text { See }\end{array}$ & $5^{\text {th }}$ & $\begin{array}{l}27 \text { September } \\
28 \text { September } \\
28 \text { September }\end{array}$ & MA & $\begin{array}{c}\text { FMA, SMA, MN, } \\
\text { R, H, dan D }\end{array}$ & $\begin{array}{c}\text { Theme } 3 \\
\text { Sub Theme } \\
2\end{array}$ \\
\hline 6 & $\begin{array}{l}\text { Plan } \\
\text { Do } \\
\text { See }\end{array}$ & $6^{\text {th }}$ & $\begin{array}{c}29 \text { September } \\
1 \text { October } \\
1 \text { October }\end{array}$ & MA & $\begin{array}{c}\text { FMA, SMA, MN, } \\
\text { R, H, dan D }\end{array}$ & $\begin{array}{c}\text { Theme } 3 \\
\text { Sub Theme } \\
3\end{array}$ \\
\hline 7 & $\begin{array}{l}\text { Plan } \\
\text { Do } \\
\text { See }\end{array}$ & $7^{\text {th }}$ & $\begin{array}{l}2 \text { October } \\
3 \text { October } \\
3 \text { October }\end{array}$ & MA & $\begin{array}{c}\text { FMA, SMA, MN, } \\
\text { R, H, dan D }\end{array}$ & $\begin{array}{c}\text { Theme } 3 \\
\text { Sub Theme } \\
3\end{array}$ \\
\hline 8 & $\begin{array}{l}\text { Plan } \\
\text { Do } \\
\text { See }\end{array}$ & $8^{\text {th }}$ & $\begin{array}{l}4 \text { October } \\
5 \text { October } \\
5 \text { October }\end{array}$ & MA & $\begin{array}{c}\text { FMA, SMA, MN, } \\
\text { R, H, dan D }\end{array}$ & $\begin{array}{c}\text { Theme } 3 \\
\text { Sub Theme } \\
3\end{array}$ \\
\hline
\end{tabular}

Table 2. Implementation Schedule for LS with an SDN 020 Tarakan Teacher as model teacher

\begin{tabular}{|c|c|c|c|c|c|c|}
\hline No & Activity & $\begin{array}{c}\text { LS } \\
\text { Cycle }\end{array}$ & $\begin{array}{l}\text { Date and } \\
\text { Month }\end{array}$ & $\begin{array}{l}\text { Model } \\
\text { Teacher }\end{array}$ & Observers & $\begin{array}{c}\text { Thematic } \\
\text { Content }\end{array}$ \\
\hline 1 & $\begin{array}{l}\text { Plan } \\
\text { Do } \\
\text { See }\end{array}$ & $9^{\text {th }}$ & $\begin{array}{l}1 \text { Oktober } \\
2 \text { Oktober } \\
2 \text { Oktober }\end{array}$ & MN & $\begin{array}{l}\text { MA, FMA, } \\
\text { SMA, R, H } \\
\text { dan D }\end{array}$ & $\begin{array}{c}\text { Theme } 4 \\
\text { Sub Theme } 1\end{array}$ \\
\hline 2 & $\begin{array}{l}\text { Plan } \\
\text { Do } \\
\text { See }\end{array}$ & $10^{\text {th }}$ & $\begin{array}{l}3 \text { Oktober } \\
4 \text { Oktober } \\
5 \text { Oktober }\end{array}$ & MN & $\begin{array}{c}\text { MA, FMA, } \\
\text { SMA, R, H } \\
\text { dan D }\end{array}$ & $\begin{array}{c}\text { Theme } 4 \\
\text { Sub Theme } 1\end{array}$ \\
\hline 3 & $\begin{array}{l}\text { Plan } \\
\text { Do } \\
\text { See }\end{array}$ & $11^{\text {th }}$ & $\begin{array}{l}7 \text { Oktober } \\
8 \text { Oktober } \\
8 \text { Oktober }\end{array}$ & MN & $\begin{array}{c}\text { MA, FMA, } \\
\text { SMA, R, H } \\
\text { dan D }\end{array}$ & $\begin{array}{c}\text { Theme } 4 \\
\text { Sub Theme } 1\end{array}$ \\
\hline 4 & $\begin{array}{l}\text { Plan } \\
\text { Do } \\
\text { See }\end{array}$ & $12^{\text {th }}$ & $\begin{array}{l}9 \text { Oktober } \\
10 \text { Oktober } \\
11 \text { Oktober }\end{array}$ & MN & $\begin{array}{c}\text { MA, FMA, } \\
\text { SMA, R, H } \\
\text { dan D }\end{array}$ & $\begin{array}{c}\text { Theme } 4 \\
\text { Sub Theme } 1\end{array}$ \\
\hline 5 & $\begin{array}{l}\text { Plan } \\
\text { Do } \\
\text { See }\end{array}$ & $13^{\text {th }}$ & $\begin{array}{l}15 \text { Oktober } \\
16 \text { Oktober } \\
17 \text { Oktober }\end{array}$ & MN & $\begin{array}{c}\text { MA, FMA, } \\
\text { SMA, R, H } \\
\text { dan D }\end{array}$ & $\begin{array}{c}\text { Theme } 4 \\
\text { Sub Theme } 1\end{array}$ \\
\hline
\end{tabular}

In learning using a process skills approach assisted by mind map media through LS, Lessons arranged was directed towards student-oriented learning. Mind maps are designed for each worksheet, and the teacher provides directions for understanding the mind map. In this LS activity, the data collection instruments were the model teacher learning implementation sheet and student worksheets to assess student learning outcomes in each cycle.

The implementation instrument refers to the lesson plan. The data used in the form of the percentage of learning implementation was assessed by the observer. Meanwhile, another instrument used is an evaluation sheet to measure student learning outcomes.

\section{Result and Discussion}

LS activities in cycles 1 to 8 were carried out with model teachers by UBT lecturers. The results of the percentage of learning implementation are shown in Figure 2 . The lowest percentage in the 1st LS cycle was $70 \%$, and the highest percentage was in the 8th cycle, which was $88 \%$. 


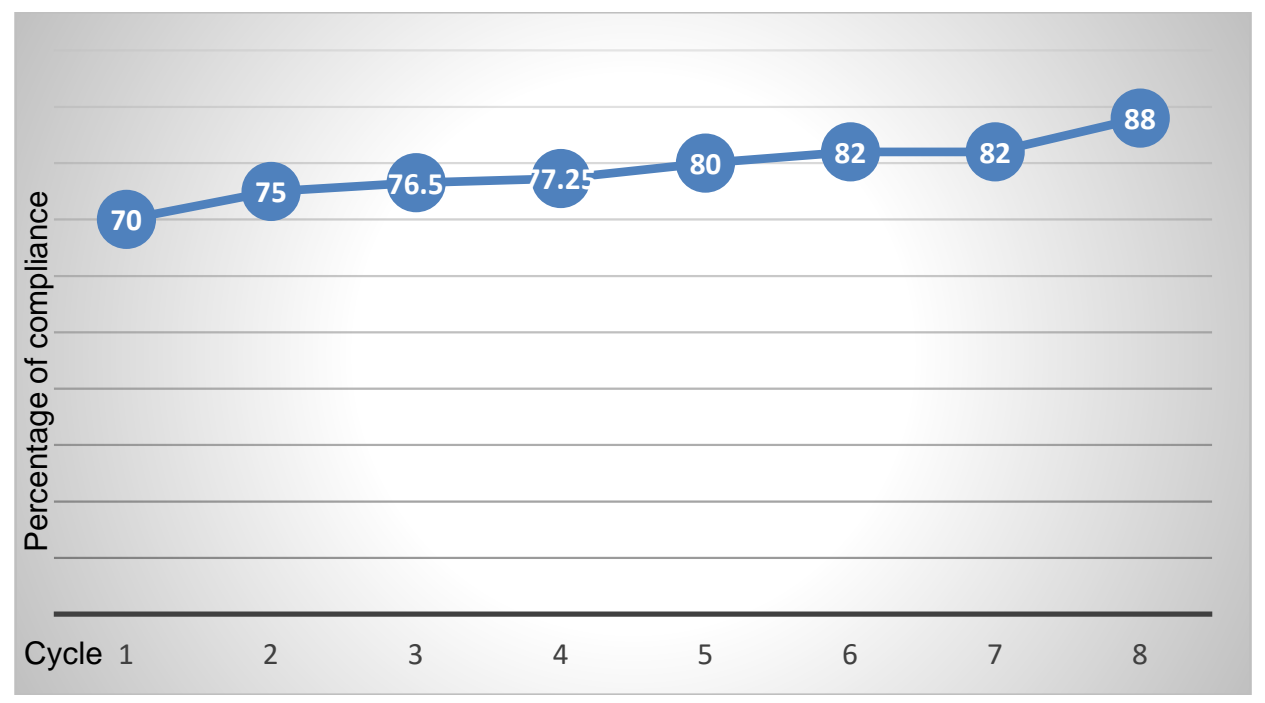

Figure 1. Percentage of Learning Implementation with Model Teachers by UBT Lecturer

The poor implementation of learning in the $1^{\text {st }} \mathrm{LS}$ cycle is due to the unfamiliarity of the model teacher in the classroom in implementing student-oriented learning. Based on the problems described in the introduction, one of the problems in the classroom is that the learning used is mostly teacher-oriented. Teachers can still not coordinate students in carrying out discussions; this is because students are still difficult to adapt to different learning conditions in their previous learning, where teachers take more roles in learning. This condition is commonly found in applying to learn with a process skills approach because, in Indonesia, this approach is very rarely used, even though the 2013 curriculum, which has been widely used in schools, emphasizes student-oriented learning. Teachers who have a minimal understanding of process skills will tend to use teacher-centered learning. This is similar to what is explained by the opinion because the quality of teacher skills in Indonesia in process skills is still very lacking so that almost the majority of teachers are more inclined to teach in a self-centered manner. Process skills also emphasize the process of observation, classification, measurement, and prediction, which will be a little challenging to adapt to in the learning process, which previously was always teacher-centered difficult for students to follow (Cantona \& Sudarma, 2020; Naj'iyah et al., 2020; I . Yusuf \& Widyaningsih, 2018).

Another problem in the 1st LS cycle is that students are still unfamiliar with the students learning the material using a mind map. Mind maps can help students in mind mapping exercises in learning; besides that, mind maps also have weaknesses at the beginning of their classroom use. The use of mind maps is closely related to students' cognitive development, especially elementary school students (Magdalena et al., 2014; Rahayu, 2016; Syam \& Ramlah, 2015). Another weakness is that students will only be programmed to think concretely rather than think abstractly

The finding in the learning process is reflected in the see stage so that the results can be considered in preparing a learning plan at the plan stage. The following is a breakdown of the results of the reflections and follow-ups that will be carried out (Table 3).

Table 3. Details of the Results of Reflection and Follow-Up (UBT Lecturers)

\begin{tabular}{lllll}
\hline No & Cycle & \multicolumn{1}{c}{ Reflection Results } & \multicolumn{1}{c}{ Follow-up } \\
\hline 1 & $1^{\text {st }}$ & - & Most students had not been able \\
& to adapt to student-centered & & - Improvements to the lesson \\
& learning conditions, especially in & & plan, especially the allocation of \\
& the discussion process, so that the & theach activity stage \\
& allocation of time is not optimal & & $\begin{array}{l}\text { Introduction to mindmaps at the } \\
\text { beginning of the lesson }\end{array}$
\end{tabular}




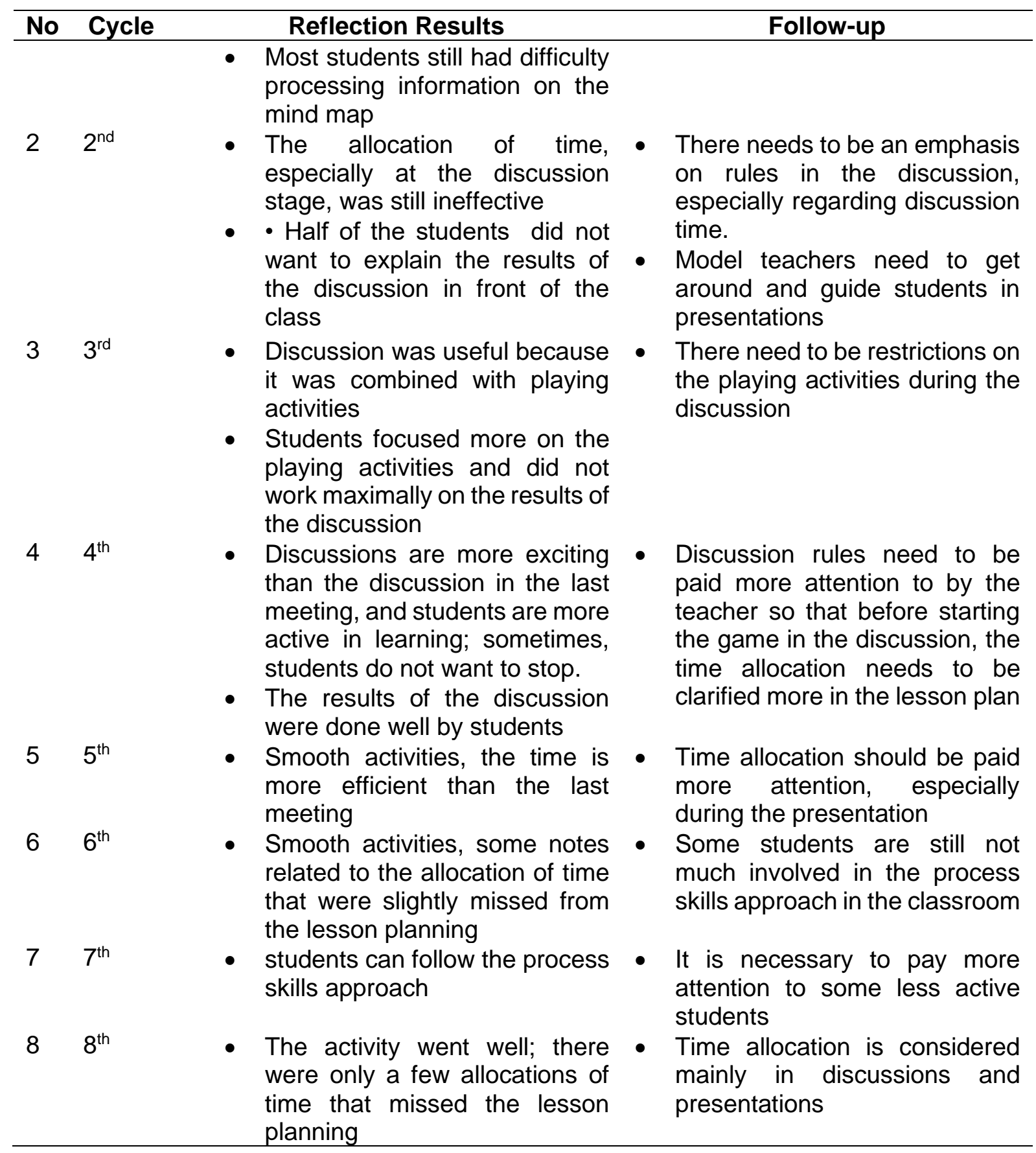

Based on the notes' results in the reflection activity at the see stage, there were two problems in implementing learning through the mind map assisted process skills approach. The problems in learning carried out by the UBT lecturer model, namely: 1) The difficulty of students in managing information/concepts in the mind map; and 2) allocation of time in learning. In general, this problem arose because students are not accustomed to taking more student-oriented learning.

Students' problems in managing information / concepts in mind maps are a fairly common problem found in several cases of using mind maps for the first time in learning. Mind maps are very helpful for students in understanding and remembering information in certain patterns, however, some researchers argue that mind maps are very uncomfortable to use in the learning process that has just applied mind maps in learning activities. This reason is due to the mismatch of the mind map structure in students' learning experiences and the need for spontaneous action in interpreting the contents of the mind map. 
The second problem encountered was time allocation. This problem is generally very often found when applying new learning models, approaches, and strategies that have never been applied to the previous learning process. Ningsih (2017) stated that the time allocation problem in learning is prevalent, especially if students are still not familiar with the new models, approaches, and strategies. It happens because of the need to adjust students' habits in learning.

Teachers of SDN 020 Tarakan carried out the 9th to 13th cycle of lesson study on doing activities. The lowest percentage value of learning implementation was in the 9th LS cycle of $77.5 \%$, while the highest percentage value was in the 13 th cycle of $89.5 \%$. Figure 3 illustrates the percentage of learning implementation.

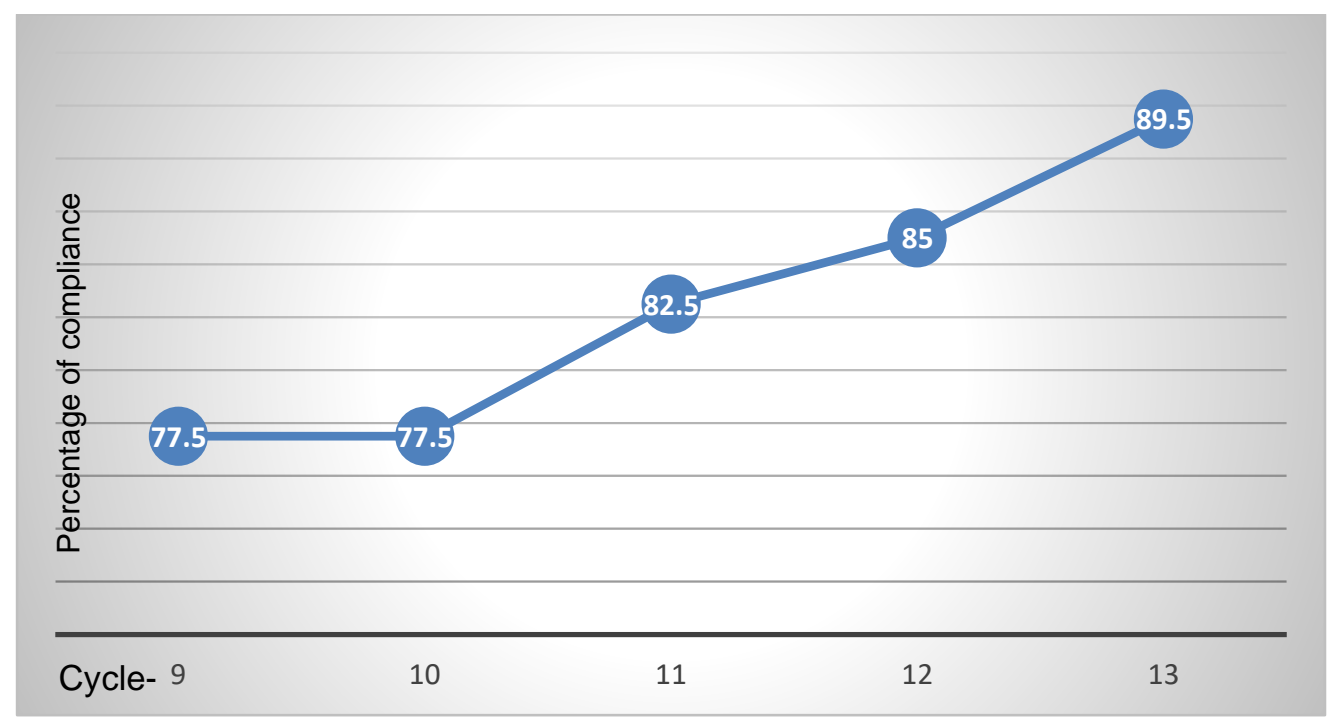

Gambar 3. Percentage of Learning Implementation with Model Teachers by SDN 020 Tarakan teachers

The percentage of learning implementation by SDN 020 teachers has a high enough value at the first meeting (9th LS cycle), which is 77.5. The cycle carried out by the teacher is an advanced cycle that has been carried out by UBT lecturers. The problems experienced by the teacher were not too many and only revolved around group organizing and classroom management. The teacher has been able to apply the process skills approach based on his observations in the LS cycle carried out by the lecturer. Like the LS cycle with the UBT lecturer model teacher, a reflection is carried out for a follow-up plan for the next lesson at the end of each lesson. The results of the reflection and follow-up of the LS cycle with the SDN 020 Tarakan teacher model are presented in Table 4.

Tabel 4. Details of the Results of Reflection and Follow-Up (SDN 020 Tarakan Teacher)

\begin{tabular}{llll}
\hline No & Cycle & \multicolumn{1}{c}{ Reflection Results } & \multicolumn{1}{c}{ Follow-up } \\
\hline 1 & $9^{\text {th }}$ & - & Teachers tended to dominate in \\
& learning activities & - & Teacher needed to pay close \\
& attention to the activities carried \\
& Student discussion activities & out so that teacher emphasized \\
& needed to be given more attention & the active participation of \\
& to allocating time & students in learning \\
& & Organizing students in \\
& & discussion activities needed to \\
& be considered so as not to \\
& waste time
\end{tabular}




\begin{tabular}{|c|c|c|c|}
\hline No & Cycle & Reflection Results & Follow-up \\
\hline 2 & $10^{\text {th }}$ & $\begin{array}{l}\text { - Teacher did not guide students in } \\
\text { the discussion; a lack of direction } \\
\text { and checking by the teacher } \\
\text { - Time allocation was not following } \\
\text { lesson planning }\end{array}$ & $\begin{array}{l}\text { - It was necessary to organize } \\
\text { and re-check the student } \\
\text { discussion process }\end{array}$ \\
\hline 3 & $11^{\text {th }}$ & $\begin{array}{l}\text { - The discussion went well, but the } \\
\text { students were still a little late in } \\
\text { completing the discussion result } \\
\text { sheet }\end{array}$ & $\begin{array}{l}\text { - Teacher was actively monitoring } \\
\text { and evaluating the overall } \\
\text { process and results of } \\
\text { discussions }\end{array}$ \\
\hline 4 & $12^{\text {th }}$ & $\begin{array}{l}\text { - Teacher was able to carry out } \\
\text { learning }\end{array}$ & $\begin{array}{l}\text { - Learning has been carried out } \\
\text { well }\end{array}$ \\
\hline 5 & $13^{\text {th }}$ & - Learning takes place smoothly & $\begin{array}{l}\text { - Learning has been carried out } \\
\text { well }\end{array}$ \\
\hline
\end{tabular}

Based on the reflection results, it can be concluded that there are two problems in implementing learning with model teachers by SDN 020 Tarakan teachers, namely: 1) teachers have problems in group organizing; and 2) teachers do not adapt in class management in student-centered learning. Group organizing is seen in organizing by the teacher in the process of ongoing discussion. Teachers tend to provide less input on discussion activities, so the discussion process is less focused. Teachers also in class management at the initial meeting tend to be teacher-centered. It happens because teachers rarely use student-oriented learning, making it difficult for teachers to apply it in the classroom. The teacher plays an essential role in classroom management. A skilled teacher will make the classroom atmosphere more lively and fun so that learning achieves the goals that have been formulated. Teachers who are skilled in managing the class will generally keep students motivated and not bored in implementing learning (Rizki, 2016; Theodora, 2016). Teachers accustomed to using monotonous teaching patterns generally find it difficult to vary the learning process, so class management is not optimal.

In addition to measuring the percentage of learning implementation, measurements are also made on learning outcomes. Student learning outcomes are measured by learning evaluation sheets. Assessment of learning outcomes in learning activities shows student learning progress during the learning process, where the evaluation sheet is adjusted to the learning objectives. Assessment of learning outcomes describes the measurement results through an evaluation sheet. The observed learning outcomes were the minimum score, maximum value, average, and standard of devotion. The 1st and 8th LS cycles' learning outcomes illustrate in Table 5, while the 9 to 13 cycles are shown in Table 6.

Table 5. Student Learning Outcomes (Teacher Model: Lecturer UBT)

\begin{tabular}{crrrr}
\hline Ls Cycle & \multicolumn{1}{c}{$\begin{array}{c}\text { Minimum } \\
\text { Score }\end{array}$} & $\begin{array}{c}\text { Maximum } \\
\text { Score }\end{array}$ & \multicolumn{1}{c}{ Average } & Standard Deviation \\
\hline $1^{\text {st }}$ & 30.00 & 87.00 & 54.0667 & 16.23732 \\
$2^{\text {nd }}$ & 38.00 & 88.00 & 58.4000 & 14.46661 \\
$3^{\text {rd }}$ & 38.00 & 86.00 & 59.6000 & 14.17769 \\
$4^{\text {th }}$ & 40.00 & 85.00 & 62.5333 & 11.87212 \\
$5^{\text {th }}$ & 55.00 & 82.00 & 66.3667 & 7.84102 \\
$6^{\text {th }}$ & 55.00 & 84.00 & 67.9000 & 8.56356 \\
$7^{\text {th }}$ & 55.00 & 82.00 & 68.8000 & 8.14693 \\
$8^{\text {th }}$ & 58.00 & 86.00 & 71.7667 & 6.64199 \\
\hline
\end{tabular}


Table 6. Student Learning Outcomes (Teacher Model: Teacher SDN 020 Tarakan)

\begin{tabular}{crrrr}
\hline Ls Cycle & \multicolumn{1}{c}{$\begin{array}{c}\text { Minimum } \\
\text { Score }\end{array}$} & $\begin{array}{c}\text { Maximum } \\
\text { Score }\end{array}$ & \multicolumn{1}{c}{ Average } & Standard Deviation \\
\hline $9^{\text {th }}$ & 60.00 & 82.00 & 71.6333 & 5.95085 \\
$10^{\text {th }}$ & 59.00 & 85.00 & 72.1667 & 6.12560 \\
$11^{\text {th }}$ & 60.00 & 80.00 & 72.3667 & 5.40423 \\
$12^{\text {th }}$ & 67.00 & 88.00 & 74.0667 & 5.18575 \\
$13^{\text {th }}$ & 69.00 & 90.00 & 74.2667 & 5.13208 \\
\hline
\end{tabular}

The quality of learning outcomes can be seen from the mean and standard deviation produced in each learning process. The higher the average, the better the value obtained, but it needs to be balanced with a smaller standard deviation. A small standard deviation will represent the data's excellent quality because the value range between the minimum and maximum values is small. In the LS cycle with the UBT lecturer model teacher, the lowest average value was obtained with the largest standard deviation in the first cycle, while the highest average value with the smallest standard deviation in the 8th LS cycle. Based on Table 5 , the results obtained for each average are increasing in each cycle. Besides, the standard deviation is getting smaller in each cycle. The low average and the immense standard deviation value in the 1st LS cycle are because students are still not used to working on discussions, so most students have not finished working on discussion sheets and impact learning outcomes. Another thing is also because students still have difficulty answering the discussion sheets given by the teacher. However, in each cycle, students continue to get used to and develop their ability to work on discussion sheets until the 8th cycle.

In the 9th to 13th cycle, the average value is higher at each meeting than in the previous cycle. In this cycle, students are getting used to answering discussion sheets so that the use of time is used more efficiently. At the standard deviation, there is an increase in the meeting value in the 9th cycle to the 10th cycle. The minimum score for students has a lower score than the previous cycle's minimum score. Learning that uses a process skills approach can train several abilities, such as observing, classifying, carrying out experiments, and communicating (Naj'iyah et al., 2020; Sayekti \& Kinasih, 2018; Sophuan, 2018). It is one of the crucial efforts to obtain optimal student learning success.

\section{Conclusions and Suggestions}

In the study of the application of lesson study through the mind map-assisted process skills approach, two things were measured in the learning process, namely: learning implementation and learning outcomes. The UBT lecturer model teacher's implementation of learning obtained the lowest score in the 1st LS cycle and the highest in the 8th LS cycle. PDS activities need to be carried out continuously by the University, because they can benefit the University itself and the school. Another suggestion is related to ongoing activities for PDS activities that can be combined with the writing of lesson study reports by teachers and lecturers in scientific articles.

\section{Acknowledgement}

Gratitude goes to the Learning Directorate of the Directorate General of Learning and Student Affairs, Ministry of Research, Technology, and Higher Education for the 2018 Lecturer Assignment activities / Penugasan Dosen di Sekolah (PDS).

\section{References}

Alamsyah, S., Annisa, M., \& Kusnadi, D. (2018). Penerapan pendekatan keterampilan proses sains untuk meningkatkan hasil belajar IPA siswa kelas V-B SDN 045 Tarakan. LENSA (Lentera Sains): Jurnal Pendidikan IPA, 8(1), 11-18. https://doi.org/10.24929/lensa.v8i1.29.

Asabe, M. B., \& Yusuf, S. D. (2016). Effects Of Science Process Skills Approach And Lecture 
Method On Academic Achievement Of Pre-Service Chemistry Teachers In Kaduna State, Nigeria. ATBU Journal of Science, Technology and Education, 9(2), 118-131. http://www.atbuftejoste.com/index.php/joste/article/view/157.

Cantona, I. G. E., \& Sudarma, I. K. (2020). Model Pembelajaran SAVI Berbantuan Media Mind Mapping Meningkatkan Hasil Belajar IPA Siswa Kelas V. Jurnal Pedaagogi Dan Pembelajaran, $3(2)$,

269-279. https://doi.org/http://dx.doi.org/10.23887/jp2.v3i2.26615.

Çepni, S. (2005). From theory to application of science and technology teaching. Ankara: Pegem Academy Press.

Hendawati, Y., Putri, S. U., Pratomo, S., \& Widianingsih, F. (2018). Penerapan Model Mind Mapping Untuk Meningkatkan Penguasaan Konsep Siswa Pada Pembelajaran IPA di Sekolah Dasar. Metodik Didaktik, 13(2), 113-124. https://doi.org/10.17509/md.v13i2.9498.

Huppert, J., Lomask, S. M., Lazarowitz, R., \& Lomask, S. M. (2010). International Journal of Computer simulations in the high school: Students ' cognitive stages, science process skills and academic achievement in microbiology. May 2013, 37-41. https://doi.org/10.1080/09500690110049150.

Magdalena, M., Rahmawati, E., \& Budiningsih, C. A. (2014). Pengaruh Mind Mapping Dan Gaya Belajar Terhadap Pemahaman Konsep Siswa Pada Pembelajaran IPA. Jurnal Inovasi Teknologi Pendidikan, 1(2), 123-138. https://doi.org/https://doi.org/10.21831/tp.v1i2.2524.

Maiza, Z., \& Nurhafizah, N. (2019). Pengembangan Keprofesian Berkelanjutan dalam Meningkatkan Profesionalisme Guru Pendidikan Anak Usia Dini. Jurnal Obsesi : Jurnal Pendidikan Anak Usia Dini, 3(2), 356-365. https://doi.org/10.31004/obsesi.v3i2.196

Merukh, N., \& Sulasmono, B. S. (2016). Pengembangan Model Supervisi Akademik Teknik Mentoring Bagi Pembinaan Kompetensi Pedagogik Guru Kelas. Kelola: Jurnal Manajemen Pendidikan, 3(1), 30. https://doi.org/10.24246/j.jk.2016.v3.i1.p30-48.

Muspawi, M. (2017). Implementasi Supervisi Akademik pada MAN Insan Cendekia Provinsi Jambi. Ta'dib: Jurnal Pendidikan Islam, 6(2), 49-56. https://doi.org/10.29313/tjpi.v6i2.3181.

Naj'iyah, A. L., Suyatna, A., \& Abdurrahman, A. (2020). Modul Interaktif Efek Fotolistrik Berbasis Lcds Untuk Menstimulus Kemampuan Berpikir Kritis Dan Keterampilan $\begin{array}{lllll}\text { Proses Sains. Jurnal Pendidikan Fisika, } & 79 .\end{array}$ https://doi.org/10.24127/jpf.v8i1.1943.

Prayitno, P. J. (2019). Pelaksanaan Supervisi Akademik Untuk Meningkatkan Kompetensi Pedagogik Guru SMA. Jurnal Visi IImu Pendidikan, 11(2), 46. https://doi.org/10.26418/jvip.v11i2.33209.

Rahayu, R. (2016). Peningkatan karakter tanggung jawab siswa SD melalui penilaian produk pada pembelajaran mind mapping. Jurnal Konseling Gusjigang, 2(1). https://doi.org/10.24176/jkg.v2i1.562.

Rizki, M. Y. (2016). Peningkatan Keterampilan Memberi Umpan Balik Guru Pendidikan Jasmani dan Kesehatan Kecamatan Taman Kabupaten Sidoarjo. Jurnal SPORTIF: Jurnal Penelitian Pembelajaran, 2(1), 72. https://doi.org/10.29407/js_unpgri.v2i1.658.

Sayekti, I. C., \& Kinasih, A. M. (2018). Kemampuan Guru Menerapkan Keterampilan Proses Sains Dalam Pembelajaran Ipa Pada Siswa Sekolah Dasar. Profesi Pendidikan Dasar, 1(1), 93. https://doi.org/10.23917/ppd.v1i1.4464.

Setiawan, D., \& Sitorus, J. (2017). Urgensi Tuntutan Profesionalisme Dan Harapan Menjadi Guru Berkarakter (Studi Kasus: Sekolah Dasar dan Sekolah Menengah Pertama di Kabupaten Batubara). Jurnal Cakrawala Pendidikan, 36(1), 122-129. https://doi.org/10.21831/cp.v36i1.11382. 
Sophuan, S. (2018). Peningkatkan Keterampilan Mengajar Guru SMP mata Pelajaran IPA Dalam Menerapkan Pendekatan Saintifik. Tadrib: Jurnal Pendidikan Agama Islam, 4(2), 335-355. https://doi.org/10.19109/tadrib.v4i2.2860.

Syam, N., \& Ramlah, R. (2015). Penerapan model pembelaajran mind mapping dalam meningkatkan hasil belajar pada mata pelajaran ilmu pengetahuan sosial siswa kelas IV SDN 54 Kota Parepare. Jurnal Publikasi Pendidikan, 5(3). https://doi.org/10.26858/publikan.v5i3.1612.

Theodora, B. D. (2016). Pengaruh Keterampilan Mengajar Guru Terhadap Hasil Belajar Siswa Sma Se-Kota Malang Yang Di Kontrol Dengan Variasi Sumber Belajar. Journal of Accounting and Business Education, 2(4). https://doi.org/10.26675/jabe.v2i4.6079.

Yusuf, I., \& Widyaningsih, S. W. (2018). Implementasi Pembelajaran Fisika Berbasis Laboratorium Virtual Terhadap Keterampilan Proses Sains Dan Persepsi Mahasiswa. Berkala Ilmiah Pendidikan Fisika, 6(1), 18-28. https://doi.org/http://dx.doi.org/10.20527/bipf.v6i1.4378.

Yusuf, M. T., \& Amin, M. (2016). Pengaruh Mind Map dan Gaya Belajar terhadap Hasil Belajar Matematika Siswa. Tadris, Jurnal Keguruan Dan IImu Tarbiyah, 1(1), 85-92. http://ejournal.radenintan.ac.id/index.php/tadris/article/view/893.

Zahro, F., Degeng, I. N. S., \& Mudiono, A. (2018). Pengaruh model pembelajaran student team achievement devision (STAD) dan mind mapping terhadap hasil belajar siswa kelas IV sekolah dasar. Premiere Educandum: Jurnal Pendidikan Dasar Dan Pembelajaran, 8(2), 196. https://doi.org/10.25273/pe.v8i2.3021. 